\title{
Big Change, Little Change? Punctuation, Increments and Multi-layer Institutional Change for English Local Authorities Under Austerity.
}

\author{
Alison Gardner \\ School of Politics and International Relations \\ University of Nottingham, UK. \\ Correspondence address: alisongardner12@gmail.com
}


This paper draws on new institutionalist theories to consider how we might characterise the process and outcomes of change occurring in English local government as a result of the UK's austerity policies. It uses national and local empirical data to argue that changes are best understood as multi-layer processes, whereby radical 'punctuated' shifts in national funding can be mitigated to incremental adjustments in service delivery at a local level. However, the paper also suggests that the incremental appearance of change may be temporary, and that diminishing institutional resilience and emergent discursive shifts potentially prefigure a paradigm change in local governance. Hall's (1993) framework of policy change is used to assess the extent of change to date. 
There is a paradox operating within English local government which has been termed an 'austerity puzzle' (Gardner and Lowndes 2016). Between 2010 and 2015 English local authorities lost more than a third of their funding (NAO 2014b, 6). Government spending reductions have subsequently been deepened and extended, meaning that some councils will lose $60 \%$ of their income by 2020 (Crewe 2016). Yet to date - and far beyond early expectations (LGA 2013) - local authorities have continued to provide or commission a wide range of both statutory and discretionary services. A 2015 Ipsos Mori poll suggested that members of the public were less likely to perceive that they had been personally affected by spending cuts in 2015 than they had been in 2012 . Respondents also consistently underestimated how far individual services had been cut (Duffy 2015).

This begs a question about the nature and extent of austerity-related change to our public service institutions. There is a tension between critical academic perspectives, which argue that austerity is acting to fundamentally re-shape the welfare state (see for instance Meegan, Kennett, Jones, and Croft, 2014; Peck, 2012; Taylor-Gooby, 2012) and new institutionalist accounts emphasising institutional resilience (John 2014; Lowndes and McCaughie, 2013). Theoretical lenses deriving from new institutionalism also diverge as to whether we should understand the process of change as a 'policy punctuation', (Jones et al., 2009) or whether institutional responses are more likely to be incremental, as described by Streeck and Thelen (2005). The final outcome of changes 
occurring in response to austerity is also contested. Hastings, Bailey Gannon et al. (2015) have discussed creeping 'residualization', focussing services on ever narrower sections of the community, and Fitzgerald and Lupton (2015) have highlighted 'limits to resilience', but practitioner discourses remain pragmatic (see for instance Lyall and Bua 2015). This suggests that there is scope for ongoing debate on whether the changes resulting from austerity are likely to prove transformative for English local government, or whether it will remain a 'great survivor' (John 2014).

This paper seeks to shed light on this empirical and theoretical puzzle by making a case for separating questions about processes and outcomes of institutional change. In referring to institutions, it looks not only at organisations, but the 'relatively enduring features of political and social life (rules, norms, procedures)' that underpin them (Mahoney and Thelen 2010, 4). It argues for a multi-layer and decentred view of institutional changes to local government, observing differing processes of change in both national and local layers, and accepting that locality is a key variable. Case study evidence is presented to demonstrate how a national punctuated change in finance may be mitigated into incremental changes in local service delivery. However, although incremental processes may appear to support the resilience narrative, reference to constructivist and discursive institutionalist theory suggests that ideational changes may be building the potential for more radical alterations in the future. Halls' (1993) framework of policy change is applied as a means to understand the outcomes of change 
to date, demonstrating that incremental change associated with austerity might nonetheless prove transformative in its effects.

\section{The nature of institutional change: analytical considerations}

A central argument of this paper is that - within the context of a multi-layer system of governance - it is possible to simultaneously observe both policy punctuation and incremental adjustment, and that both of these mechanisms have the potential to result in either incremental or transformative change to outcomes. To help illustrate this point, the analysis draws a deliberate distinction between the process of change occurring and the outcomes of that change.

Minor adjustments do not always result in minor change. Drawing on Dahl and Lindblom's theories about incremental policy making, Cope (1994) argues that it is possible that a decision made incrementally could lead to a large change, and a decision made non-incrementally could produce a small change (Cope 1994, 341). Goodin also highlights the difficulty of predicting the scale of change arising from minor adjustments, highlighting the possibility of both 'threshhold' and 'sleeper' effects, which can result in sudden and significant change (Goodin 1982, 24). Modern historical institutionalists also argue that gradual adjustment can be transformative over the longer term (Streeck and Thelen 2005, 9) and conversely, that policies which appear 
to effect radical change when witnessed at close hand may prove to have a relatively limited effect on institutions when reviewed with adequate hindsight (Pierson 1994, 14). In considering the change occurring as a result of austerity, it is therefore important to differentiate between processes and outcomes.

\section{Processes of change}

New institutionalist theory provides differing models for change processes with some disagreement on the pace of change. For example Jones et al. (2009) argue that although patterns of public spending in the US are generally characterised by incremental change, they also show 'punctuated' instances of major change. Using the geological metaphor of plate tectonics, they speculate that standard operating procedures, cultural norms, human perceptions and increasing institutional costs create 'a retarding force that interferes with the smooth adjustment of political systems to incoming information' (Jones et al. 2009, 867). In the face of reductions in public expenditure, existing systems and policies 'stick' until sufficient friction builds for a rapid change, akin to an earthquake, although it is difficult to predict when a tipping point may occur.

A more gradual (though still potentially transformative) process of change is offered by Streeck and Thelen, who suggest that gradual endogenous change takes place 
through processes of displacement, layering, conversion, and drift (Streeck and Thelen 2005, 31; Lowndes and Roberts 2013, 128). 'Displacement' describes the act of replacing or subordinating one set of institutional rules with another, sometimes with rules that have previously been suppressed. 'Layering' occurs when new rules are superimposed on previous ones, leading to the compromise and eventual defeat of the original rules. 'Conversion' involves adapting existing rules and structures to new agendas through a process of reinterpretation. 'Drift' describes the neglect of rules in response to changes in the environment, leading to slippage of practice on the ground. Streeck and Thelen also describe a final category of 'exhaustion' which is more akin to punctuated equilibrium, in that it encompasses a situation where the environment has changed to the extent that existing institutions are no longer viable or appropriate.

In a context of multi-layer governance, punctuated and incremental processes of change can exist side by side. Locality is a key variable in this process. Several studies have demonstrated that austerity in England has been distributed unequally through decisions on grant funding and programme cuts leading to variation in the extent of the external shock (Audit Commission 2013; Hastings et al. 2013; NAO 2013). In addition national processes of institutional change are mediated by local factors including resilience and agency. The need underlying a service may be met in many different ways, and there is no automatic link between funding, volumes, outputs and outcomes (Lipsky 2010, 178). 
Pierson identifies four potential sources of institutional resilience: co-ordination, veto points, asset specificity, and positive feedback $(2004,142)$. He describes how institutional stability is sometimes associated with the maintenance of co-ordination, where existing institutions constitute a stable position or equilibrium, of shared benefit to powerful actors, with strong disincentives to explore alternative approaches. Turning next to 'veto points', Pierson suggests institutions are more resilient if changes or challenges need to be agreed in a 'self-referencing' way by actors who have disincentives to altering the status quo. Third, Pierson describes 'asset specificity', suggesting that actors with an interest in assets, such as relationships, expectations, and knowledge of procedures, are likely to support the continuation of activity wherever those assets are applied $(2004,148)$. Meanwhile, 'positive feedback', including the support of key interest groups, makes the removal of institutions unattractive and their replacement increasingly costly. He suggests that 'all other things being equal, an institution will be more resilient, and any revisions more incremental in nature, the longer the institution has been in place' (Pierson 2004, 147 emphasis Pierson's own). By using these categories as a framework for analysing local responses to austerity, we can begin to understand how and where local resilience has delayed processes of change.

Agency is a further variable affecting change processes. Mahoney and Thelen describe four different types of change agent within institutions, working from very 
different motivational positions; Insurrectionaries, Subversives, Symbionts, and Opportunists (2010, 23). Understanding differentiation in the objectives and motivations of change agents is especially useful in a local government context, because it takes into account that actors will have differing levels of power and divergent motivations or political positions, affecting their desire to promote change, or maintain stability. The relative influence of each type of change agent can provide further clues to explain how change has been facilitated or resisted.

In assessing processes of institutional change we should therefore take into account the experience of different layers of governance, the capacity for resilience and the influence of agency. But how might we understand outcomes of change? Strong caveats must be offered on any tentative judgements: the relatively recent inception of austerity-related approaches mean that change-to-date may not be a fair reflection of change over a longer time frame. Nonetheless, the experience of six years of radical austerity, and the recent arrival of a new UK Prime Minister and Chancellor, makes this an opportune moment for reflection.

\section{Outcomes of change}

In seeking to review the extent of change, it is important to recognise outcomes in terms of changes to ideas as well as structure. A focus solely on formal and informal 'rules of 
the game' as they are expressed in a material sense could negate significant discursive and ideational shifts which have the capacity to generate institutional instability. In his discussion of constructivist institutionalism Colin Hay $(2006,66)$ suggests that ‘ideational change invariably precedes institutional change'. Vivien Schmidt also emphasises the way in which discursive institutionalism complements other types of institutionalism by providing a means to understand (often unexpected) change against structural and material background factors (Schmidt 2008, 314).

Discursive and material elements are combined in Peter Hall's (1993) study of economic policymaking. Hall outlines three 'orders' of policy change:

- First order change describes changes in the levels or settings of policy instruments, whilst the overall goals and instruments of policy remain the same.

- Second order change; suggests changes to the techniques or instruments used to attain policy goals.

- Third order change; argues for changes in all three components of policy; instrument settings, the instruments themselves and the hierarchy of goals behind the policy. Hall describes this type of change as 'rare' with an example being the shift from Keynesian to monetarist modes of macroeconomic regulation. (278-279).

This framework can be operationalised in relation to local governance. Whilst alterations to the 'settings' and 'instruments' of first and second order change might 
manifest in a local governance setting as material changes to budgets and institutions (see table 1), Hall's third order 'paradigm' change is primarily discursive; involving changes to 'a framework of ideas and standards that specifies not only the goals of policy and the kind of instruments that can be used to attain them, but also the very nature of the problems they are meant to be addressing' (Hall 1993, 279).

\section{Table 1 here.}

Hall also suggests that his paradigms can be 'competing' or 'not fully elaborated' (1993, 291) suggesting that transformational shifts may not always be distinct. The model is somewhat limited by its linear nature, the categorisation implying a stepped or staged approach (whereas Hay and Schmidt's perspectives suggest that we might see third order policy change before second order change is observed.) However, for the purposes of this analysis, Hall's framework provides a helpful starting point for analysing outcomes of change enacted in response to austerity, albeit with a strong degree of caution.

\section{Case study and methods}

In applying the theoretical framework outlined above, this paper has drawn on both national and local data, gathered between 2013 and 2015 in the course of doctoral 
research into how local public services were responding to austerity. National observations are drawn from a literature review and secondary data, whilst local observations relate to a single exploratory case study of institutional responses to austerity across a Labour-controlled urban unitary local authority area.

The single case study approach was chosen as a means to observe effects of austerity beyond comparison of cuts to services, considering discursive and ideational consequences, as well as material effects. A deep understanding of local context was critical to this analysis, and might have been obscured by a larger ' $n$ ' study. The approach acknowledges austerity's contingent and localised impacts, including differential effects from the recession and varying distribution of spending cuts. It is rooted in an epistemological perspective which does not deny the material effects of austerity policies, but accepts that 'realities' of austerity are localised and specific (Furlong \& Marsh 2010, 190; Peck 2012, 647).

The selected case provided an excellent exemplar of the 'austerity puzzle' in practice, experiencing a cash-terms reduction in 'revenue spending power' of $22 \%$ between 2010 and $2015^{1}$. Employment in the local area had been severely impacted by the recession and subsequent spending cuts, due to a high reliance on the service sector and public sector employers. The locality also had a legacy of poverty and deprivation,

\footnotetext{
${ }^{1}$ Revenue spending power represents UK Government's assessment of funding available to each local authority to spend on core services. It rests on a contested formula, but is recognised by the National Audit Office as the most reliable means for wider financial comparison (NAO 2014b, 24)
} 
being amongst the top 20 most deprived local authority areas in the country. Yet despite delivering more than $£ 100$ million of savings (in the context of a 2010 revenue budget of $£ 273$ million), an analysis of budget lines using a framework drawn from Hastings et. al. (2013) showed that only $5 \%$ of savings arose from reductions in the range of services provided. At the same time, resident satisfaction with the area and local authority services climbed from a low base to above the national average, and the local authority was nationally recognised for innovation in transport and energy management (Gardner 2016, 144-157).

Fieldwork used a collaborative action-research approach, involving budgetary analysis, a document review, two workshops with frontline service teams and a total of 34 semi-structured interviews. Interviews cited within this article include three executive councillors (EM 1, 2 3), four council directors (CD 1, 23 and 4), an interview with two former council directors (CFD) one council middle manager (CM1) and five Council frontline officers (CO 1-5) as well board members from different partner agencies engaged in in local service delivery (PBM 1-5).

The validity of the research was tested in a variety of ways (following Lather 2003). 'Construct validity' was strengthened through the application of multiple theoretical perspectives and research methods. Potential researcher bias was mitigated through the action-research strategy, which required reflexivity coupled with a stakeholder-reviewed collaborative approach to research design. 'Face validity' was 
established through the maintenance of dialogue with research subjects and the distribution and discussion of findings. Data triangulation was enhanced by mixed methods, and in the case of workshops, observer triangulation.

Two key propositions are considered, rooted in the austerity puzzle conundrum. The first proposition considered processes, positing that if austerity-related change was indeed minimal, change processes would be characterised by incremental change, rather than 'punctuated equilibrium'. The second proposition addressed outcomes, suggesting that austerity policies would be delivered with minimal (first order) change to local governance and systems. Although the findings in relation to the single case cannot be generalised to apply to other localities and contexts, they can be generalised to theory (following Yin, 1994) and are utilised in this paper to explore these propositions and the theoretical framework outlined above.

\section{National and local processes of change: from punctuation to mitigation}

A strong case can be made for viewing the emergency budget and Comprehensive Spending Review of 2010 as a national financial policy punctuation, understanding punctuation as 'a discontinuous pattern, characterised by a large sudden shift in attention that departs from a long period of stability' (John and Bevan 2012). The 28 per cent cuts (HM Treasury 2010) to local government's central grant funding instigated in 
2010 represented an unprecedented reversal in public spending, unequalled since the second world war (Taylor-Gooby 2012). Changes to local government's grant formula were accompanied by a de-coupling of the previous link between rates of deprivation and funding, with a regressive redistributive effect, meaning the difference in spending between English authorities in the most and least deprived bands fell from 45 per cent in 2010/11 to just 17 per cent in 2014/15 (Hastings et al. 2015, 16).

Yet despite this punctuation, the changes in institutional processes observed in the local case study were initially characterised by minor adjustments to services, with savings mainly being achieved through cuts to the 'back office' and internal restructuring. However, it was possible that this phase of incrementalism was temporary. By the latter half of the spending review period, tried and tested mechanisms to achieve savings were starting to be supplemented by more radical approaches.

The analysis produced evidence for an evolving approach to managing the 'budget gap' (Hastings et al. 2013, 15), which moved from an incremental approach of minor cuts or 'salami-slices' from departmental budgets, to seeking more substantial savings through ambitious transformation programmes. Whilst a core set of policy priorities were protected, there was a marked shift between 2010 and 2015 from incremental savings to more fundamental re-design of services. This did not happen in a radical moment of change; indeed one director commented, 'I don't think this is a place that 
does radical, because the ideology is quite traditional in some ways' (CD1). Instead, although outward policy 'rules' were maintained, it was possible to detect changes to the informal elements which underpinned institutions of service delivery. These changes could be related to Streeck and Thelen's (2005) categories of conversion, layering, displacement, and drift.

For example, in relation to its workforce management, the council 'converted' its policy justification for staff benefits during the period of study, from being a 'good employer' to highlighting advantages for improved efficiency. 'Layering' was apparent in the way in which the council overlaid the strength of council-provided contract services with what one manager termed 'a more energetic appetite' for external commercial activity (CM1). 'Displacement' accurately described a controversial policy of exchanging the voluntary and community sector grant funding system for a new 'commissioning' process, which distributed funding through contracts awarded on a competitive basis. There were also changes in core policies around eligibility for services and grants, and cuts to early intervention schemes, consistent with concepts of policy drift and exhaustion. As policies shifted, fresh debates also opened on the norms and aspirations for service provision, with one interviewee explaining that the council's aims had changed from acting as a paternalistic provider, to a situation where communities were being left to 'sort themselves out' (CO1). 
Whilst such subtle shifts were appreciable mainly to actors within the system, they represented a destabilisation of the institutions underpinning service delivery. The gradual move towards more radical responses could be likened to the pace of an athlete on a treadmill which was speeding up: as the pace (or requirement for budgetary savings) became more challenging, the strides (or movements away from existing ways of doing things) began to increase. In summary, the radical financial punctuation had been mitigated into small, incremental shifts, but the transformational potential of those incremental changes, which suggested different goals of service delivery and challenged formerly dominant narratives, was increasing as time progressed.

\section{The erosion of institutional resilience from national and local perspectives}

Using Paul Pierson's ideas on institutional resilience it is also possible to see how sources of institutional resilience, which would normally act to prevent the revision of local government institutions, were gradually being eroded.

For example in relation to co-ordination, the council had historically defended its identity as a local service provider, circumventing laws on compulsory competitive tendering. National policies to promote outsourcing had generally been resisted by both council members and officers (CD2, EM3, CO4, CO5) and bringing services back 
in house was encouraged, although this was justified on cost, rather than ideological grounds (EM3).

Nonetheless, it was clear from the local case that - whilst it was defending a role in service delivery - market-driven approaches to co-ordination were growing in importance in comparison to state-driven models. This was evidenced by the exploration of outsourcing in relation to specific functions (CD2, CD4) growth in commissioning approaches and moving from 'gift' or grant-based relationships with the voluntary sector to 'transactional' commissioning-based relations (CFD). Although the adoption of commercial practices was presented as a twist on state co-ordination (CD3, EM3) this tactic also acknowledged the dominance of a market-driven philosophy of service delivery. There had also been some withdrawal from the council's community co-ordination activities, making space for other partners to exercise some of its local 'convening' functions. In effect, state-centred approaches were being challenged and eroded as the council's financial power reduced, and market-driven and communitarian approaches were increasingly influential.

Turning next to 'veto points', from a national perspective, councils remained highly constrained legally, financially and politically. For example, the 2011 Localism Act had installed what Pierson terms a 'self-referencing' institutional veto against raising Council Tax above a limit set annually by central government. Councils were 
theoretically able to hold local referenda to increase taxes, but had very strong political disincentives to taking that path (NAO 2014, 33). ${ }^{2}$

Locally, gaps between legislation and implementation provided some leeway for local interpretation, with one director commenting 'we do what we want to do anyway. People think local government has these edicts they have to work to, but if they are not locally appropriate you can find a way around them' (CD2). Yet as another director noted, open insurrection was also relatively rare, especially when it involved court action (CD4). Elected members were clear that they could not set an unbalanced budget, and their only route was to 'manage despite the cuts' (EM3, CO1). Thus, although the council was able to mitigate the effects of financial reductions on services, it had little scope to prevent those effects within the limits of its own veto.

In relation to 'asset specificity' and 'positive feedback', although English local government as an institution dates back to the $19^{\text {th }}$ century, its physical, professional and political assets, have come under a sustained attack at national level, pre-dating austerity. Physical assets such as council housing and property have been systematically reduced. The rise of new public management techniques in the 1990s weakened the power-base of the local government professions, whilst local government

\footnotetext{
${ }^{2}$ A 4.75 per cent Council Tax rise which would have triggered a referendum was explored by Brighton and Hove Council in 2014, but eventually rejected by opposition parties. In 2015 the Police and Crime Commissioner in Bedfordshire triggered a local referendum when he proposed a rise of 15.8 per cent in the Council Tax allocated to policing. The proposal was rejected.
} 
unions were neutralised under the 'new' Labour government (Laffin 2009, 27). These factors may have contributed to the uncontested 16.6 per cent reduction in the staff base between 2010 and 2013 (NAO 2014b, 8). Local politics has also been weakened in processes stretching back many years; anxiety about local electoral turnout was evident in the early years of the 'new' Labour governments (DETR 1998; Cole 2003). With diminishing physical assets, professional interests, and popular support, local government lacks sources of 'positive feedback'.

Compared to this national context, the local case nonetheless had some features which enhanced its institutional resilience. The council had a large property portfolio, managed through a number of trusts, which allowed it to use land and property to strengthen inter-organisational bonds, generate income, and facilitate investment (EM3). A high level of political continuity promoted stability in relationships between council members and other civic elites, supporting increasing depth and maturity of high-level partnership collaboration. The council had also been consistent in its policy of protecting assets relating to service delivery, such as the bus company and district heating system. Such building blocks were crucial as the basis for innovation and delivery of initiatives such as a light rail project and local energy company, despite the context of spending cuts.

Despite this, the council was not able to entirely insulate itself from the erosion of assets. Although not excessive in the context of similar areas, the reduction in staff base 
was 23 per cent between 2010 and 2013. This loss of personnel, coupled with a drop in financial power, contributed to changes in relationships with some partners; from a trust and support based environment to a more contract-led basis; and from the ability to promote direct action, to an environment where progress depended on influence and 'wheeling and dealing' (PBM3). Shared services (provided jointly with other councils) were being piloted in relation to human resources and payroll, and new management models were being explored with other statutory agencies, such as the police.

Drawing together this evidence on the processes of change, it can be argued that as processes of institutional change appeared to accelerate, our local case study's sources of resilience were also being steadily eroded. The council had less influence and choice in the form of 'co-ordination' it provided; self-referencing veto points prevented contestation of the cuts; assets specific to the local authority were under pressure; and there was limited positive feedback to sustain the current institutional forms: indeed these were already changing.

\section{Processes of local agency}

The effect of individual actors on local change processes was complex, indeed elements of institutional 'maintenance, defence, revision and discovery' (Streeck, cited in Lowndes and Roberts 2013, 136) could be observed from the interviews. In considering 
the role of actors, the analysis adapted Mahoney and Thelen's (2010, 23) definitions to take account of how actors worked to maintain or undermine institutions and contest institutional change (as well as enact it) against the external shock of austerity. In this analysis, insurrectionaries became the defenders of institutions, who wished to preserve local services against prevailing financial pressure; subversives aimed at maintenance, providing the appearance of conformity with change, but using loopholes to pursue an anti-austerity agenda; symbionts outwardly supported the organisation's stance on austerity, but had sympathy with some objectives of austerity policies and the aim of 'never wasting a good crisis'; whilst opportunists were intent on discovery, looking for creative possibilities within change.

Although opportunities for outright insurrectionary resistance to austerity were severely constrained, interviews certainly showed evidence of a politically-inspired defence against the ramifications of the spending cuts and welfare reform. One policy officer commented that 'everything's a fight', alluding to resistance to welfare reform proposals (CO3). Another frontline officer said she was 'impressed' with how vocal the council had been in contesting the 'bedroom tax' $(\mathrm{CO} 2)$. Certain routes for achieving savings also remained taboo, with outsourcing considered as a 'red line' for many interviewees (CD2, EM3, CO4, CO5).

More commonly there was evidence for 'subversion' as apparent compliance with the government's agenda was subtly aligned with the council's policy priorities. A 
repeated refrain was that the council was 'not taking it lying down' $(\mathrm{CO} 3, \mathrm{CO} 4)$ with activity in opposition to central policies taking place in the 'grey area' between legislation and implementation (CD2). This included, for example, a commitment to funding welfare rights in order to maximise benefits take up; an unwritten policy of trying to avoid evictions related directly to the 'bedroom tax' (EM2), and the mobilization of 'commercialisation' in a way that could 'take us back to big council departments' (CD3).

However amongst interviewees, and particularly senior officers and partners, there were also examples of 'symbionts' who sought to use the pressures arising from austerity to promote revision of processes and institutions. These included the director who described commercialism as a 'Trojan horse' to get councillors 'into the right territory for a sensible discussion' (CD1) and partners who were keen to radically reform the existing shape of the public sector (PBM 2, PBM5). A private sector service provider commented that the officer body sometimes tended to behave as a 'small c' conservative force, but that the ' $\mathrm{C}$ ' had become bigger with retrenchment, inferring that officers were now using right-wing values in designing and implementing policies. The extension of cost-driven commissioning approaches was cited as an example of these values in practice (PBM4).

It could also be argued that the mantle of 'symbiont' could in some senses also be extended to senior politicians, as by committing to 'manage within the cuts', the 
political leadership had created a context where compromises were inevitable. One director referred to the sense of compromise, saying that members had, in the main, 'been able to navigate the difference between their policy differences and staying true to their values, to minimise the worst impact of it, but it has been hard' (CD1).

There were also a number of examples of opportunism, embodied in actors who were seeking to discover new models of delivery. These included members, partner organisations and council staff who were seeking to explore how to shift the balance of power and responsibility between the council and the community (EM1, CO2, Workshop 2014b). Another example of opportunism in action was the move to use the context of austerity to re-define the central / local relationship, through arguing for devolution in combination with freedom from central grant funding (CD3).

In practice the council found itself drawing on all these motivations and perspectives to identify novel ways of meeting the budget gap. The outcome of this diverse agency was essentially that in the short-term the punctuated change instigated by budget cuts was being modified. As one senior manager put it austerity had not 'derailed the agenda' and was being actively mitigated 'within constraints' (CM1). However, as the financial pressure grew, defensive and maintenance-focussed strategies championed by insurrectionaries and subversives were supplemented by novel and revisionist proposals from symbionts and opportunist players. This was demonstrated by comments showing how austerity was encouraging policy makers to embed reforms 
that had formerly been resisted. One director commented that 'we've really softened up the boundaries over the years. We had to say "please don't stifle the ideas"” (CD1). Another longstanding director reflected that some of these changes had multiple antecedents, for instance greater involvement of the private sector could be traced back to the use of Private Finance Initiative (PFI) and Local Improvement Finance Trust (LIFT) schemes for health-related capital investment. As he put it, such delivery mechanisms 'became the routes available to provide bread and butter as opposed to the cream, it's happened organically' (CD4).

To summarise, although it is possible to agree that the local change processes instigated in response to austerity were initially characterised by incremental change rather than 'punctuated equilibrium', this may have been the result of mitigating responses, which could be temporary in their effects. Over the longer term institutional and agential sources of resilience were being challenged as the financial pressure acted to embed change at a material and discursive level. In effect our case study provided a working example of what Pierson terms 'longer term incremental changes', which are 'typically invisible' in studies of political phenomena, but 'crucial in creating the preconditions for institutional reform' $(2004,164)$. By considering the outcomes of austerity related change, the next part of this paper will assess how far that reform has progressed to date. 


\section{Outcomes of change}

Whilst a longer time scale and greater historical distance is arguably needed to properly appreciate the long-term outcomes of austerity measures, Hall's framework of first second and third order policy change assists in taking stock of the extent of change to date.

\section{A) Evidence for first order change: changing the settings}

There is extensive national and local evidence for 'first order change' or alterations to the 'settings on the instruments' within local government, interpreting 'settings' as budgetary changes, changes in functions and service volumes. Over a longer time scale, analysis could also include service quality, but data on changes to service quality is only starting to emerge, and thus remains an item for future research to consider in more detail.

While the extent of budgetary reductions is disputed between national and local actors, it is plain that substantial budget reductions have occurred, in our case study amounting to a (minimum) cash terms reduction of 22 per cent in revenue spending power between 2010 and 2015/16. The majority of savings to date were being delivered through 'efficiencies', including the 23 per cent cut to the overall staff base and significant reductions in the amounts paid to other service providers. This in turn led to 
a reduction in the volume of some services, for instance in community development, youth and highways services, plus reductions in contract value, impacting for instance on early intervention services to prevent homelessness. The picture in our case is consistent with wider research which has shown that budget reductions were initially managed through efficiency savings and reductions in service volumes, rather than reductions in the range of functions (Audit Commission 2013, 5; NAO 2014b, 33; Hastings et al., 2015: 609). More extensive retrenchment is thought to be likely in the future as opportunities for efficiencies are exhausted (Hastings et al. 2013).

\section{B) Evidence for second order change: changing the instruments}

Second order change implies changing the techniques or instruments of policy in pursuit of policy goals. In local government's case the implication would be moving away from traditional structures and institutions to new forms of delivery. This type of change is also in evidence both nationally and locally, although in many cases traditional institutional bodies still persist alongside new delivery mechanisms.

In the national layer we can see increased austerity driving the adoption of 'shared services' between councils and cross-border collaboration: in 2015 there were 416 shared service arrangements occurring between councils across the country delivering in $£ 462$ million of efficiency savings, compared to 173 such arrangements in 2012 (Local 
Government Association 2015). Inter-agency collaboration has also been promoted by the integration of public health with local government in 2013 , and although this change was not wholly driven by austerity, siting public health in local councils has resulted in challenges to the costs of local public health interventions (Iacobucci 2014).

There have also been innovations in institutional form for the purposes of economic development, including sub-regional Local Enterprise Partnerships (LEPs), combined authorities, and devolution of additional tax-raising powers (conditional on installation of 'metro mayors'). This emerging institutional form is closely linked to arguments for creating economically viable city-regions, which could eventually be governed without central government grant funding (Core Cities 2013). Despite being promoted as a 'devolution revolution' (Osborne 2015) the strategy is also arguably a policy manoeuvre to transfer accountability for austerity-related cuts (Lowndes and Gardner 2016).

In our case study, changes to policy instruments were at an early stage, but nonetheless in evidence. Shared services, management, and combined authority arrangements were under discussion. Although there had been surprisingly little change to the formal organisational arrangements at least one partner felt that public sector integration could be taken much further (PBM2). At an ideational level, the development of commercialisation could be seen as an alternative type of second order change, introducing a fresh set of policy instruments to achieve the council's objectives. 
Equally significant were areas where the council was transferring responsibilities to service users and local communities (CM1, CO1, CO5).

\section{C) Evidence for third order change: changing the goals}

If first and second order change can be identified, is there also evidence for a more fundamental third order change?

Multiple commentators have argued that austerity is being used by the Coalition (and now Conservative) government to advance an ideological agenda which aims to dismantle the welfare state and embed neo-liberal policy agendas into public services (see for instance Clarke and Newman 2012; Levitas 2012; Newman, 2013; TaylorGooby and Stoker 2011; and Wilks-Heeg 2011). To date institutions have endured the spending cuts, but there have been warnings that further cuts are unlikely to be achieved whilst maintaining existing institutions and meeting existing statutory requirements (Hastings et al. 2013; NAO 2014a). In Hall's terms the 'policy anomalies' and 'frequent policy failures' that presage a major third order change may be starting to appear on the radar, embodied - for instance - in recurrent political debates about affordable housing and funding for adult social care.

Given this national context, to what extent can symptoms of third order change be detected locally? The case study examined here remains a solid Labour council, having 
maintained that position for more than 25 years, making it - at least in theory - less open to the ideological drivers behind austerity. Yet despite the outward appearance of stability, we have discussed how our council's institutions were being challenged at a narrative and discursive level, moving from state centred models of service delivery to an ethos more closely identified with market-led forms of co-ordination. It could therefore be argued that the steady financial pressure accompanying austerity was eroding the 'third order' goals of the organisation, forcing political compromise and narrowing expectation of what the local state could achieve. A partner articulated this shift commenting that the 'neo-liberal agenda has been taken on board uncritically' there was a need to 'become a more progressive authority' (PBM1). Although such reflections were not widely expressed by officers and members, subtle shifts in policies and discourses suggested that austerity had the potential to be transformative in its long term effects.

\subsection{Conclusions}

This paper has used national and local data to explore the nature of change resulting from austerity, arguing that it is possible, in a multi-layer governance context, to have different processes of change occurring simultaneously. It has also suggested that the process of change is not necessarily a determinant of the change outcome, helping to 
explain how shifts that - at surface level - appear subtle and incremental can nonetheless underpin transformation. Thus the theoretical tensions outlined in the 'austerity puzzle' at the beginning of this paper can be resolved within this framework: local authorities may indeed be resilient, and change processes appear incremental, but it is too early to rule out the possibility of a punctuated shift in public services, or fundamental 'third order' change.

In the case study locality, despite the national policy punctuation, organisations had (mainly) retained their form, albeit under considerable pressure, and actors had combined to devise ways of navigating the crisis. However, the increasingly radical steps needed to meet budget deficits meant that this mitigation seemed likely to be temporary. Regarding the outcomes of change, although (in Hall's terms) second order changes remained fairly minimal, this was in line with the theory that ideas underpinning institutions at a discursive level would change before institutions were altered at a material level (Hay 2006). The goals of local public service delivery were actively under debate amongst key local actors, potentially presaging a third-order transformation in local services.

The framework outlined in this paper would clearly be enhanced by testing over a longer time period, to examine whether discursive shifts eventually re-shape the sticky instruments of governance, or whether other 'threshold' or 'sleeper' effects from incremental adjustments emerge to promote significant change (Goodin 1982, 24). It 
could also form the basis for an examination of institutional change in comparative perspective; exploring what processes and outcomes of change are observed in areas with distinct political contexts, asset bases, and relative levels of grant cuts. These factors, in combination with a nuanced consideration of the role of agency, could teach us much about the basis of local government's resilience to date.

From a policy perspective, Coalition policy architects should also be wary of assumptions that austerity is a policy 'success', having apparently delivered transformative change without disruptive punctuations in services at the frontline. Whilst it is true that a legislative, financial and normative framework has restricted councils with opposition political views from exercising extensive resistance, 'punctuated' policy shifts may be only temporarily delayed. Hall highlights that policy anomalies presage third order change, and Baumgartner and Jones also caution that 'prior to a major quake there is seismic activity' (Baumgartner and Jones 2002, 296). Reports in the press have highlighted that increasing numbers of councils are entering severe financial difficulties and in danger of becoming insolvent (Municipal Journal 2015a; Municipal Journal 2015b). The referendum decision for 'Brexit' is also likely to impact most severely - in terms of withdrawal of European funding - on those areas that have already borne the most radical spending cuts (Beatty and Fothergill 2013).

With this in mind, the time is perhaps ripe for a wider and more purposeful policy conversation on the institutions appropriate to the emerging discursive paradigm that 
frames our public services. To date austerity has been a largely reactive process, with policy responses such English 'devolution', constrained by a narrow menu of options designed to fit existing structures, boundaries and funding models. A more forwardlooking dialogue between academics, practitioners and policymakers, recognising the new goals and contexts of service delivery, could perhaps contribute towards more imaginative, effective and resilient institutional responses. 


\section{Bibliography}

Audit Commission. 2013. Tough Times 2013. London: Audit Commission.

http://www.audit-commission.gov.uk/wp-content/uploads/2013/11/Tough-Times2013e4.pdf.

Baumgartner, Frank, and Bryan Jones. 2002. Policy Dynamics. Edited by Frank R. Baumgartner and Bryan D Jones. Chicago: University of Chicago Press.

Beatty, Christina, and Steve Fothergill. 2013. Hitting the Poorest Places Hardest. Sheffield: Sheffield Hallam University. https://www.shu.ac.uk/research/cresr/sites/shu.ac.uk/files/hitting-poorest-placeshardest_0.pdf.

Clarke, J., and J. Newman. 2012. "The Alchemy of Austerity.” Critical Social Policy 32 (3): 299-319. doi:10.1177/0261018312444405.

Cole, Michael. 2003. “Local Government Reform in Britain 1997-2001: National Forces and International Trends." Government and Opposition 38 (2): 181-202.

Cope, Stephen. 1994. The Making of Spending Cuts in Local Government : A Case Study of Four English Local Authorities, 1984/85. PhD diss., London School of Economics.

Core Cities. 2013. Competitive Cities, Prosperous People. A Core Cities Prospectus for 
Growth. Manchester: Core Cities.

http://www.corecities.com/sites/default/files/images/publications/Competitive Cities, Prosperous People_Final Draft.pdf.

Crewe, Tom. 2016. "The Strange Death of Municipal England" London Review of Books, 38 (24).

Davies, Jonathan S, and Madeleine Pill. 2012. "Empowerment or Abandonment? Prospects for Neighbourhood Revitalization under the Big Society.” Public Money and Management 32 (3): 193-200.

DETR. 1998. Modern Local Government: In Touch with the People. London. http://www.politicsresources.net/docs/DETR1998.pdf.

Duffy, Bobby. 2015. “Coming to Terms with Austerity?” Ipsos Mori Website. https://www.ipsos-mori.com/researchpublications/researcharchive/3644/Comingto-terms-with-austerity.aspx?view=print.

Furlong, Paul, and David Marsh. 2010. “A Skin Not a Sweater, Ontology and Epistemology in Political Science.” In Theory and Methods in Political Science, edited by David Marsh and Gerry Stoker, 3rd ed., 184-211. Basingstoke: Palgrave Macmillan.

Gardner, Alison. 2016. How are local public services responding to austerity? 
Unpublished $\mathrm{PhD}$ Thesis, University of Nottingham

http://eprints.nottingham.ac.uk/32349/

Gardner, Alison, and Vivien Lowndes. 2016. "Negotiating Austerity and Local Traditions." In Rethinking Governance. Ruling, Rationalities and Resistance, edited by Mark Bevir and R.A.W Rhodes, 125-43. London: Routledge.

Goodin, Robert E. 1982. Political Theory and Public Policy. Chicago: The University of Chicago Press.

Hall, Peter A. 1993. "Policy Paradigms, Social Learning, and the State: The Case of Economic Policymaking in Britain.” Comparative Politics 25 (3): 275-96.

Hastings, Annette, Nick Bailey, Kirsten Besemer, Glen Bramley, Maria Gannon, and David Watkins. 2013. Coping with the Cuts? Local Government and Poorer Communities. York: Joseph Rowntree Foundation. http://www.jrf.org.uk/publications/coping-with-cuts.

Hastings, Annette, Nick Bailey, Glen Bramley, Maria Gannon, and David Watkins. 2015. The Cost of the Cuts: The Impact on Local Government and Poorer Comunities. York: Joseph Rowntree Foundation. http://www.jrf.org.uk/publications/cost-cuts-impact-local-government-and-poorercommunities. 
Hastings, Annette, Nick Bailey, Maria Gannon, Kirsten Besemer, and Glen Bramley. 2015. "Coping with the Cuts? The Management of the Worst Financial Settlement in Living Memory." Local Government Studies 41 (4): 601-21. http://www.tandfonline.com/doi/full/10.1080/03003930.2015.1036987.

Hay, Colin. 2006. “Constructivist Institutionalism.” In The Oxford Handbook of Political Institutions, edited by R Rhodes, S Binder, and B Rockman, 56-74. Oxford: Oxford University Press.

HM Treasury. 2010. Spending Review 2010. London: The Stationery Office. http://cdn.hm-treasury.gov.uk/sr2010_completereport.pdf.

Iacobucci, Gareth. 2014. "Raiding the Public Health Budget.” BMJ 348 (April 2014). doi:10.1136/bmj.g2274.

John, Peter. 2014. "The Great Survivor: The Persistence and Resilience of English Local Government.” Local Government Studies 40 (5): 687-704. http://www.tandfonline.com/doi/abs/10.1080/03003930.2014.891984.

John, Peter, and Shaun Bevan. 2012. "What Are Policy Punctuations? Large Changes in the Legislative Agenda of the UK Government, 1911-2008.” Policy Studies Journal 40 (1): 89-108. doi:10.1111/j.1541-0072.2011.00435.x.

Jones, Bryan, Frank Baumgartner, Christian Breunig, Christopher Wlezien, Stuart 
Soroka, Martial Foucault, Abel François, et al. 2009. “A General Empirical Law of Public Budgets : A Comparative Analysis.” American Journal of Political Science 53 (4): 855-73.

Laffin, Martin. 2009. “Central-Local Relations in an Era of Governance: Towards a New Research Agenda.” Local Government Studies 35 (1): 21-37. doi:10.1080/03003930802574698.

Lather, Patti. 2003. "Issues of Validity in Openly Ideological Research: Between a Rock and a Soft Place." In Turning Points in Qualitative Research: Tying Knots in a Handkerchief, edited by Yvonna S. Lincoln and Norman K. Denzin, 185-215. Walnut Creek, CA: AltaMira Press.

Levitas, R. 2012. “The Just's Umbrella: Austerity and the Big Society in Coalition Policy and beyond." Critical Social Policy 32 (3): 320-42. doi:10.1177/0261018312444408.

Lipsky, Michael. 2010. Street-Level Bureaucracy. 30th Anniv. New York: Russell Sage Foundation.

Local Government Association (LGA). 2013. Funding Outlook for Councils from 2010 / 11 to 2019 /20. London: LGA. http://www.local.gov.uk/c/document_library/get_file?uuid=b9880109-a1bc-4c9b- 
84d4-0ec5426ccd26\&groupId=10180.

Local Government Association. 2015. "National Map of Shared Services" 2015. LGA

Website. http://www.local.gov.uk/shared-services-map.

Lowndes, Vivien, and Alison Gardner. 2016. "Local Governance under the

Conservatives: Super-Austerity, Devolution and the 'smarter State."' Local

Government Studies 42 (3): 357-75. doi:10.1080/03003930.2016.1150837.

Lowndes, Vivien, and Kerry McCaughie. 2013. "Weathering the Perfect Storm?

Austerity and Institutional Resilience in English Local Governance.” Policy \& Politics 41 (4): 533-49.

Lowndes, Vivien, and Mark Roberts. 2013. Why Institutions Matter: The New Institutionalism in Political Science. Basingstoke: Palgrave Macmillan.

Lyall, Sarah, and Adrian Bua. 2015. "Responses to Austerity: How Groups across the UK Are Adapting, Challenging and Imagining Alternatives.” London: New Economics Foundation.

http://www.neweconomics.org/publications/entry/responses-to-austerity.

Mahoney, James, and Kathleen Thelen. 2010. “A Theory of Gradual Institutional Change.” In Explaining Institutional Change, edited by James Mahoney and Kathleen Thelen, 1-37. Cambridge: Cambridge University Press. 
Meegan, Richard, Patricia Kennett, Gerwyn Jones, and Jacqui Croft. 2014. “Global Economic Crisis, Austerity and Neoliberal Urban Governance in England.” Cambridge Journal of Regions, Economy and Society 7 (1): 137-53.

Municipal Journal (MJ). 2015a. "Island Deal Vital to IoW Survival.” Municipal Journal, no. 3rd September: 1.

MJ. 2015b. "West Somerset 'Teetering on Edge.'” Municipal Journal, no. 10th September 2015: 1 .

National Audit Office (NAO). 2013. Financial Sustainability of Local Authorities. London: The Stationery Office. http://www.nao.org.uk/wpcontent/uploads/2013/03/Local-Authority-Full-Report.pdf.

NAO. 2014a. Financial Sustainability of Local Authorities 2014. London: National Audit Office. http://www.nao.org.uk/report/financial-sustainability-of-localauthorities-2014/.

NAO. 2014b. The Impact of Funding Reductions on Local Authorities. London:

National Audit Office. http://www.nao.org.uk/report/the-impact-funding-reductionslocal-authorities/.

Newman, J. 2013. "Landscapes of Antagonism: Local Governance, Neoliberalism and Austerity." Urban Studies 16 (1): 1-16. doi:10.1177/0042098013505159. 
Osborne, George. 2015. “George Osborne’s Full Speech to Tory Conference.” Www.politicshome.com. https://www.politicshome.com/partypolitics/articles/news/george-osbornes-full-speech-tory-conference.

Peck, Jamie. 2012. “Austerity Urbanism.” City 16 (6): 626-55.

Pierson, Paul. 1994. Dismantling the Welfare State? : Reagan, Thatcher, and the Politics of Retrenchment. Cambridge : Cambridge University Press,.

Pierson, Paul. 2004. Politics in Time. Princeton, New Jersey: Princeton University Press.

Schmidt, Vivien. 2008. "Discursive Institutionalism: The Explanatory Power of Ideas and Discourse.” Annual Review of Political Science 11 (1): 303-26. doi:10.1146/annurev.polisci.11.060606.135342.

Streeck, Wolfgang, and Kathleen Thelen. 2005. "Introduction: Institutional Change in Advanced Political Economies." In Beyond Continuity: Institutional Change in Advanced Political Economies, edited by Wolfgang Streeck and Kathleen Thelen. Oxford: Oxford University Press.

Taylor-Gooby, Peter. 2012. "Beveridge Overboard? How the UK Government Is Using the Crisis to Permanently Restructure the Welfare State." Intereconomics 47 (4): 224-29. 
Taylor-Gooby, Peter, and Gerry Stoker. 2011. "The Coalition Programme: A New Vision for Britain or Politics as Usual?” The Political Quarterly 82 (1): 4-15. doi:10.1111/j.1467-923X.2011.02169.x.

Wilks-Heeg, S. 2011. “'You Can’t Play Politics with People’s Jobs and People’s Services': Localism and the Politics of Local Government Finance." Local Economy 26 (8): 635-51. doi:10.1177/0269094211422190.

Workshop. 2014. "Outer Estate Multi-Agency Team”

Yin, Robert K. 1994. Case Study Research Design and Methods. 2nd ed. Thousand Oaks, California: Sage. 


\begin{tabular}{|l|l|l|}
\hline \multicolumn{2}{|l|}{ Table 1: Institutional change outcomes } \\
change & Order of change & Application to this study \\
\hline Material & $1^{\text {st }}$ order (settings) & Budgetary changes, adjustments to functions, \\
& service volumes and quality. \\
\hline Material & $2^{\text {nd }}$ order & Implies a move away from existing structures \\
& (instruments) & and institutions, to new forms of delivery. \\
\hline Discursive & $3^{\text {rd }}$ order (goals) & Implies a change in political values / goals \\
\hline
\end{tabular}

Source: (Hall 1993) plus author's analysis 